\title{
NARRATIVAS JORNALÍSTICAS E INSURGÊNCIAS SECUNDARISTAS: 0 aparecer de demandas dissensuais em disputa'
}

\author{
JOURNALISTIC NARRATIVES AND SECONDARY STUDENTS' \\ INSURGENCIES: the emergence of dissenting demands in dispute
}

\author{
Francine ALTHEMAN² \\ Escola Superior de Propaganda e Marketing (ESPM)| Brasil \\ Ângela Cristina Salgueiro MARQUES ${ }^{3}$ \\ Universidade Federal de Minas Gerais | Brasil
}

\begin{abstract}
Resumo:
$\mathrm{O}$ artigo busca revelar como narrativas jornalísticas desempenham um papel central no desenho de quadros de visibilidade e legibilidade para as ações políticas de jovens secundaristas de São Paulo em 2015. Elas não só operam normatividades por meio da proposição de enquadramentos, mas também compõem cenas polêmicas e intervalos dissensuais nas disputas de sentido. O percurso metodológico é composto por 30 matérias jornalísticas de diferentes veículos acerca da ocupação da Escola Estadual Fernão Dias (SP), que configuradas em uma rede de elementos, promovem uma operação narrativa que redefine o aparecimento político de jovens insurgentes. Revelamos como a composição dessa rede pode permitir a elaboração de um trabalho de resistência que Rancière (2019) define como "desmontagem do olhar".

Palavras-chave

movimento secundarista; narrativas jornalísticas; cenas de dissenso.

\section{Abstract}

The article seeks to reveal how journalistic narratives play a central role in the design of visibility and legibility frameworks for the political actions undertaken by young secondary students in São Paulo, in 2015. They not only operate normativities through the framing proposition, but they also compose polemical scenes and dissensual intervals in disputes about meaning. The methodological path consists of 30 journalistic articles from different vehicles about the occupation of the Fernão Dias State School (SP). Such journalistic texts, when brought together in a network of elements, promote a narrative operation that redefines the political appearance of young insurgent students. We reveal how the composition of this network can allow us to elaborate an operation of resistance that Rancière (2019) defines as "the disassembly of the gaze".

Keywords

secondary movement; journalistic narratives; scenes of dissensus.
\end{abstract}

RECEBIDO EM 20 DE MARÇO DE 2021

ACEITO EM 17 DE JUNHO DE 2021

\footnotetext{
${ }^{1}$ Este trabalho contou com apoio do CNPq e da FAPEMIG. As autoras agradecem aos pareceristas ad hoc da revista Âncora pelas ótimas contribuições feitas ao trabalho.

2 Doutora em Comunicação Social pela UFMG, autora da tese vencedora do prêmio Compós 2021. Mestre em Comunicação na Contemporaneidade pela Faculdade Cásper Líbero e jornalista graduada pela Unesp. Professora do curso de Jornalismo da ESPM-SP. Contato: franaltheman@gmail.com. 3 Professora do Programa de Pós-Graduação em Comunicação Social da UFMG. Pós-doutora em Ciências da Informação e Comunicação pela Université Stendhal, Grenoble III. Contato: angelasalgueiro@gmail.com.
} 


\section{Aात्बिरू}

Francine ALTHEMAN - Ângela MARQUES

\section{Introdução}

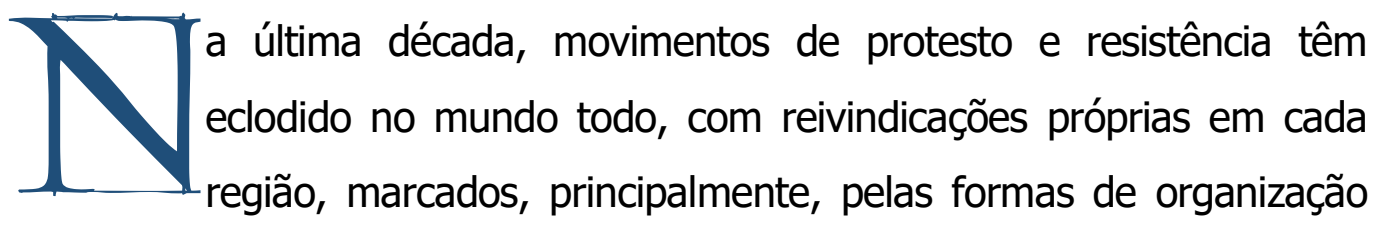
coletiva de ocupação do espaço público. Esses movimentos surgem na África, contra ditaduras na Tunísia, no Egito e no Iêmen; na Europa, especificamente na Espanha e Grécia, onde aconteceram ocupações e greves por melhores condições de trabalho; no Chile, pela gratuidade da educação; nos Estados Unidos, contra a corrupção no setor financeiro e a desigualdade econômica e social. No Brasil, as Jornadas de Junho de 2013, que tiveram como estopim a luta pelo transporte público, contra o aumento da tarifa proposto pelos governos, abrem um espaço para os movimentos de protesto se intensificarem e surgem como uma referência para mobilizações coletivas insurgentes.

Tais movimentos marcam o século 21 e se desdobram em articulações situadas e multiterritorializadas, em grandes cidades do mundo, por meio de protestos em massa e ocupações de espaços urbanos que não se configuraram da noite para o dia: compõem uma historicidade que desenha linhas de resistência capazes de evidenciar importantes pontos em comum entre os diversos levantes acima mencionados, como a tomada das ruas, novas formas de organização e mobilização, a repressão policial como resposta dos governos para criminalizar o movimento, a horizontalidade e a experimentação de outros arranjos possíveis para a promoção de alianças que possam desestabilizar ordens hierárquicas e desequilibrar hegemonias. Além disso, não indicam representantes e evitam ligações com partidos, sindicatos ou organizações tradicionais, e engendram processos comunicativos autônomos e independentes, alicerçados no uso das redes sociais digitais, que se distanciam e contestam os modos de fazer e construir enquadramentos postos em prática pelos veículos de comunicação que dominam o cenário midiático. 
No final de 2015, com forte inspiração nos movimentos de resistência que estavam acontecendo no mundo, na Revolta dos Pinguins (Chile) e nas Jornadas de Junho no Brasil, estudantes do Estado de São Paulo iniciam um levante, que traz muitas das características desses movimentos de insurgência: horizontalidade, apartidarismo, inspiração no novo anarquismo, ocupação do espaço público, que se transformam em espaços de trocas, resistência e experimentações, uso criativo das redes sociais digitais, e um engajamento atrelado à subjetividade e à transformação de si (MARQUES e ALTHEMAN, 2020).

O movimento secundarista em São Paulo teve início, principalmente, por causa da proposta de reorganização escolar anunciada pelo governo do Estado em setembro de 2015, que ameaçava fechar 94 escolas e afetar outras 56 em todo o Estado. Os estudantes não só ocuparam as ruas de dezenas de cidades, como também criaram espaços de discussão nas escolas e nas redes sociais digitais, fomentando a repercussão do movimento na mídia, tanto em veículos tradicionais como nos veículos de comunicação alternativos.

Em pesquisa realizada nos últimos quatro anos, foi observado como esse gesto político dos jovens de São Paulo revelou que um levante pode ser caracterizado como experimentação, contrariando expectativas e rompendo com roteiros pré-determinados que definem um campo de experiência bem marcado por normas, institucionalidades e divisão dos tempos e espaços. As ocupações evidenciaram que escolas e ruas podem ter suas espacialidades e temporalidades redefinidas pela ação coletiva de jovens atores políticos e sua presença física articulada. Novas e potentes formas de legibilidade e inteligibilidade dos acontecimentos são elaboradas nessas experimentações e ocorrem rupturas de campos de experiência determinados pela regra e por dispositivos de controle.

Permeando as cenas que compõem o movimento secundarista, mostrou-se importante observar como as narrativas jornalísticas 


\section{ANIEORA}

Francine ALTHEMAN - Ângela MARQUES

desempenham um papel central no desenho de quadros de visibilidade e legibilidade para as ações empreendidas pelos jovens: elas não só operam normatividades por meio da proposição de enquadramentos, como também, a partir de dentro de tais normas, podem produzir fraturas nas regularidades que delineiam os enunciados e compõem as cenas que conferem inteligibilidade aos acontecimentos.

É esse recorte, a partir do olhar para as narrativas jornalísticas mais tradicionais, que apresentamos nesse artigo. De modo a compreender esse tensionamento em sua dinamicidade comunicativa, analisamos um total de 30 reportagens, veiculadas nos principais veículos de comunicação do país no período de 23 de setembro de 2015 a 15 de dezembro de 2015, que abordaram a ocupação da Escola Estadual Fernão Dias, uma das principais ocupações daquele período, que ganhou muita visibilidade por ser uma escola de região nobre da cidade de São Paulo. Foram selecionadas matérias dos veículos de comunicação considerados de maior circulação em São Paulo, como os jornais Folha de S. Paulo e O Estado de S. Paulo; as revistas Época, Veja e Carta Capital; os portais de notícias como UOL (do Grupo Folha) e G1 (do Grupo Globo). Além disso, também buscamos narrativas elaboradas pelos Jornalistas Livres e pelo El País Brasil, uma vez que promovem uma cobertura na qual os jornalistas tendiam a se envolver mais fortemente com os acontecimentos, tornando-se, muitas vezes, ativistas da situação, abrindo espaço para as vozes dos secundaristas e promovendo enquadramentos não usuais. Importante salientar que ao redor de uma dada questão problemática há sempre vários conjuntos de interpretações que a envolvem e que sofrem mudanças ao longo do tempo, providenciando novas interpretações e sentidos acerca de seus pontos principais de tensão. Uma das principais atribuições do enquadramento delineado pelos media é, nesse sentido, a de fornecer uma idéia organizadora central capaz de produzir sentido a partir de eventos relevantes e sugerir o que está em questão (MENDONÇA; SIMÕES, 2012). 0 
enquadramento dispõe, assim, esquemas interpretativos que produzem e organizam, sentidos acerca do mundo, de nossas relações e dos eventos que os atravessam. Justamente por isso ele está relacionado ao modo como desigualdades e assimetrias de poder se enraízam nas interações cotidianas (BUTLER, 2018).

Nossa aposta é a de que as operações narrativas que definem o "aparecer" dos secundaristas pode tanto reafirmar quanto desafiar o modo hierárquico de apresentação de uma insurgência, reiterando ou rearranjando a legibilidade e as condições de apreensão dos sujeitos e de suas demandas. A aproximação e comparação entre narrativas jornalísticas derivadas de distintas fontes, em exercício crítico e reflexivo, pode nos permitir a elaboração de um dispositivo que Rancière (2019, p.51) chama de "máquina de desmontagem do olhar"4. Quando articulamos diferentes registros narrativos, ampliamos as chances de indeterminação da produção de sentidos, ou seja, da impossibilidade de fixar o destino e a significação dos textos e imagens, desestabilizando esquemas de inteligibilidade do que estava programado para poder ser visto.

A análise se baseia na comparação entre narrativas que remetem a formas distintas de fixação e apresentação de panos de fundo morais e éticos associados às ações insurgentes em questão. Nossa proposta é refletir sobre as narrativas jornalísticas como textualidades que compõem as cenas de ocupação das escolas. Para a análise, recorremos ao pressuposto de Leal (2013), que entende que as narrativas jornalísticas podem se configurar como um modo de compreender o mundo, conferindoIhe sentido a partir de seus enquadramentos, mas também compreendemos

\footnotetext{
${ }^{4}$ Rancière (2019) nos alerta para o fato de que uma cena, ou seja, uma operação de interrupção da maneira usual de explicação, divisão e legibilidade das experiências, não equivale a um dispositivo. Ele afirma se afastar de Foucault quando monta uma cena, pois a questão do poder e das normas que nos controlam e nos constituem não seria o foco de operação da cena, mas sim a maneira como arranjos e rearranjos são feitos nas materialidades que nos conduzem para apreender, ler e pensar o mundo e os sujeitos que nele habitam. A nosso ver, as cenas são "arranjos disposicionais" (na acepção de José Luiz Braga), mas não dispositivos de controle.
}

João Pessoa - Brasil | ANO 8 VOL.8 N.1 | JAN./JUN. 2021 | p. 121 a 152 


\section{ÂN[ORA}

Francine ALTHEMAN - Ângela MARQUES

que a narrativa jornalística revela uma rede de significados, não reduzindo sua potencialidade à representação dos acontecimentos. Segundo ele, podemos apreender os textos jornalísticos em suas múltiplas textualidades como práticas sociodiscursivas historicamente situadas, considerando-os em processos de mútuos tensionamentos com temporalidades e espacialidades socialmente articuladas, em meio a clivagens e contradições, nas quais múltiplos atores sociais estão envovidos em disputas de sentido e jogos de poder. As redes configuradas pelas textualidades orientam processos narrativos que dinamizam não só os enunciados e enunciações sociais, mas dinamizam e dialetizam os vínculos que configuram o tecido comum que nos une.

Tal abordagem privilegia uma perspectiva orientada para as operações de sentido que sejam qualitativamente significativas para a reconstrução da cena desse acontecimento público e para compreender a forma como narrativas jornalísticas ajudam a compor o "aparecer"5 de jovens estudantes que ocuparam as escolas em 2015, e cujo grito reverbera ainda entre nós e nas teias narrativas que nos ajudam a compor e recompor cenas de dissenso. Sendo assim, não caberia, neste cenário, a formulação de uma pesquisa sistemática, baseada em códigos previamente configurados. Entendemos que a análise, a partir da leitura de Rancière $(2016,2018)$ e Didi-Huberman (2016b, 2019), está ancorada nas possibilidades de fazer aparecer diversas narrativas que compõem as cenas, ou seja, ao reunir imagens, documentos e relatos, entre eles aqueles veiculados pelos veículos de comunicação, é possível revelar as representações que revelam as fissuras que transformam as cenas de dissenso.

${ }^{5}$ O aparecer ou aparição é um gesto estético-político que Rancière $(2018,2019)$ utiliza para definir a forma como os sujeitos devem criar a cena de sua visibilidade: o momento em que aqueles que não têm lugar para falar na sociedade podem fazer sua demanda ser ouvida e considerada, podem mudar as condições de inteligibilidade e audibilidade em uma cena de enunciação específica. 


\section{A reconstrução da cena de insurgência}

Uma cena polêmica dissensual, no sentido utilizado por Rancière (2009, 2018), é composta de dois movimentos: uma fabulação do tempo e do espaço nos quais os atores "aparecem" e se fazem ver e ouvir; e uma montagem operada por aquele que relata as singularidades que tornam a cena única, mas ao mesmo tempo conectada a vários eventos e processos mais amplos. A cena tem dois significados essenciais para Rancière: ela é a síntese do método da igualdade e, ao mesmo tempo, o locus da constituição performática do sujeito político e da partilha política do sensível:

No conceito de cena há a escolha de um certo modo de racionalidade: pensamos na espessura de um acontecimento singular, podemos ler o conjunto dos vínculos que definem uma singularidade política, artística ou teórica. Trata-se de colocar em relação o que aparece como sem relação, ou de mostrar uma capacidade que parece não mais existir. Penso que a questão da cena é também ligada muito fortemente à questão da aparência, ao fato de que a aparência não é o contrário da realidade, mas a cena da manifestação. A teatralidade é a construção de um outro universo de aparências: o fato de fazer aparecer o que não aparecia, ou de fazer aparecer de forma diferente o que aparecia sob um certo modo de visibilidade e inteligibilidade (RANCIÈRE, 2018, p.14).

Sobre o método da igualdade, que está associado diretamente ao processo de reconstrução das cenas, Rancière (2016) ressalta que ele consiste em procurar nas narrativas das pessoas a subversão de uma performance da desigualdade. Isso acontece prioritariamente na construção e escrita de sua experiência sensível, que implementa um "como se" diferente que desloca a lógica que o remete a um dado lugar social. Não há aqui um uso das artes, da literatura e da escrita como instrumento de libertação da consciência e instauração de uma revolução contra as opressões. Na verdade, Rancière aposta em um reenquadre da situação de opressão: ela não deixa de existir, porém há uma transformação molecular dos afetos que permitem uma abertura a novas percepções. 


\section{ANIEORA}

Francine ALTHEMAN - Ângela MARQUES

Esse processo envolve, portanto, a narrativa dos sujeitos envolvidos no acontecimento, neste caso, dos secundaristas, que podem aparecer como falas, performances, expressões artísticas, cartazes, aparições públicas etc., mas também uma narrativa performada por outros atores sociais que tomam parte do acontecimento, como os jornalistas que fazem a cobertura desse evento e constroem, de alguma forma, uma narrativa midiática que também ajuda a reconstruir as cenas de insurgência.

É preciso compreender, dessa forma, que as autoras deste artigo montam a cena da ocupação: identificam nos acontecimentos uma descontinuidade temporal e sensível, um corte no tempo uniforme e nos modos naturalizados de percepção, que permitem outra apresentação da legibilidade política dos sujeitos e dos corpos. São as autoras que evidenciam como a transformação promovida pela cena não é radical ou imediata, mas permite a identificação de singularidades através das quais podemos pensar uma série de mudanças possíveis de ocorrerem a longo prazo. Por fim, são as autoras que traçam uma articulação e elaboram montagens que "expõem as diferentes formas como uma mesma coisa pode ser percebida, configurando um momento no qual as coisas podem vacilar, ser sacudidas" (RANCIÈRE, 2018, p. 31).

A reconstrução da cena envolve mais do que a mera descrição do acontecimento. $O$ processo está permeado por cenas que se abrem dentro de cenas, pelas teias discursivas que vão se entrelaçando, pelas perspectivas dos documentos e narrativas usados para essa fabulação, pelas narrativas dos atores principais desse movimento, os secundaristas, e pela perspectiva das pesquisadoras. Ou seja, é uma rede de feixes discursivos e comunicacionais que se entrelaçam na reconstrução da cena, entre eles a reprodução do acontecimento pelo olhar midiático, que se liga automaticamente ao método da igualdade. 
A cena é uma entidade teórica peculiar ao que chamo de método da igualdade, porque ela simultaneamente destrói as hierarquias entre os diferentes níveis de realidade e discursos; e os métodos usuais para julgar se um fenômeno é importante. A cena é o encontro direto entre o mais particular e o mais universal. Nesse sentido, é o exato oposto da generalidade estatística.[...] Eu construo a cena como uma pequena máquina na qual o máximo número de sentidos pode ser condensado em torno de uma questão central, que é a questão da partilha do mundo sensível. A partir dessa base construo a cena e a considero como tal, como função de sua capacidade de desafiar todos os conceitos ou discursos, todas as ficções que lidam com as mesmas questões, ou seja, qual relação existe entre o fato de ter ou não ter tempo, e o fato de ser capaz ou não de pensar (RANCIÈRE, 2016, p.74).

A experiência e o acontecimento que reconstrói as cenas de insurgência se configuram também por meio das imagens, mas não são imagens quaisquer. São as imagens produzidas durante o ato da disputa política, ou seja, no momento da ocupação da escola e no momento da chegada da polícia. São imagens conflituosas, performáticas, em que aquele que filma também é um manifestante. Muitos jornalistas, que se colocam no meio dessa disputa política, também acabam se inserindo no movimento como manifestantes, atuando muitas vezes como um dispositivo de proteção, já que eles gravam as movimentações dos jovens o tempo todo, em plano sequência, expondo a violência policial à opinião pública. Ao se colocarem no meio da resistência política com a câmera, o corpo político desses agentes se configura numa força e numa ação de reconfiguração acerca das quais tentaremos evidenciar, sob o viés comunicacional, alguns aspectos centrais.

Dessa forma, acreditamos que as narrativas jornalísticas acerca das insurgências secundaristas, tomadas em uma rede complexa de aproximações e interfaces, podem promover a aparição de demandas capazes de dialetizar o visível e nos tornar sensíveis às experimentações políticas promovidas pelos jovens estudantes nas ocupações de escolas, ruas e redes. Tal argumento conduz a abordagem a ser desenvolvida nesse texto, procurando encontrar, nos arranjos e composições criadas pelas narrativas jornalísticas, os intervalos 


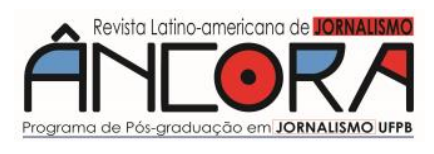

Francine ALTHEMAN - Ângela MARQUES

a partir dos quais figuram os povos vulneráveis, tornando sensível uma aproximação, um avizinhamento mais demorado entre os espectadores e as formas de vida abrigadas por tais narrativas.

Para reconstruir as cenas da ocupação da Escola Estadual Fernão Dias, nossa proposta nesse artigo, foi necessário olhar para as narrativas dos secundaristas (presentes nas redes sociais, em documentários e nas matérias jornalísticas $)^{6}$, seguindo o pressuposto proposto pelo método da igualdade, mas também nos debruçarmos sobre documentos diversos, como imagens, vídeos, publicações nas redes sociais digitais e reportagens veiculadas nos principais veículos de comunicação de São Paulo, que nos ajudam a remontar as cenas da ocupação.

Esses documentos, imagens e textos, quando associados às narrativas dos estudantes, promovem uma articulação de olhares possíveis sobre a forma como os secundaristas e as ocupações podem "aparecer" para o público e como esse acontecimento foi narrado midiaticamente.

\section{A ocupação da escola Fernão Dias}

A Escola Estadual Fernão Dias foi a segunda escola do Estado de São Paulo a ser ocupada - a primeira escola foi a E. E. Diadema. No entanto, essa escola acabou se tornando uma espécie de símbolo das escolas ocupadas. Ela foi ocupada na madrugada de 10 de novembro de 2015, por voltas das 5 horas da manhã, menos de 12 horas depois que a E. E. Diadema foi ocupada. A estratégia adotada pelos secundaristas nessa ocupação foi entrar na escola de madrugada, quando não haveria nem alunos, nem professores e diretores, e

\footnotetext{
${ }^{6}$ Entre as fontes de narrativas dos secundaristas estão: a) o documentário: LUTE como uma menina! Direção e produção: Flávio Colombini e Beatriz Alonso. São Paulo: 2016; b) a reportagem: LIVROS abertos, escolas ocupadas. Produção: Douglas Lambert. Fotografia e reportagem: Lígia Roca, Maíra Cabral, Marcus Leoni, Renan Lopes e Ricardo Lerman. São Paulo: TV Folha, 2015. Grande-reportagem (10 min); c) o documentário FERNÃO: o legado das ocupações. Direção e produção: Beatriz Morrone. São Paulo: 2016. Documentário, Trabalho de Conclusão de Curso da PUC-SP (89 min); d) ACABOU a paz. Isso aqui vai virar o Chile. Direção e produção: Carlos Pronzato. São Paulo: 2016. Documentário (60 min); e) o documentário Espero tua (Re)volta. Direção e produção: Eliza Capai. Documentário, 93 min. Globo Filmes, 2019.
} 
trancar o portão para que ninguém mais entrasse sem autorização (somente os alunos que chegavam para as aulas da manhã puderam entrar na escola). Assim foi feito e a escola amanhceu ocupada, com a aulas interrompidas e com a convocação de assembleias, que se seguiram durante todo o período de ocupação.

O colégio, que fica no bairro de Pinheiros, na capital paulista, um dos metros quadrados mais caros de São Paulo, ocupa um quarteirão inteiro e parece mais um museu do que uma escola. No amplo jardim na entrada tem uma estátua do bandeirante Fernão Dias, com a inscrição "caçador de esmeraldas", pichada pelos estudantes com a palavra "assassino". O Fernão, com seu jardim, sua arquitetura de casarão antigo e grades vazadas que deixam a rua à mostra, destoa das demais escolas estaduais periféricas, que parecem mais com presídios de que com instituições de ensino.

Até o final de 2015, a comunidade de Pinheiros não se importava muito com aquele casarão, que acabou virando protagonista do bairro depois do movimento secundarista. Durante a ocupação, o Fernão foi cercado por mais de cem policiais e por jornalistas, que centralizaram ali as principais coberturas da mídia sobre o acontecimento. Entre simpatizantes e opositores, as ruas do entorno do colégio ficaram tomadas, durante todo o período de ocupação, por um pessoal que não era muito visto por ali. Essa repercussão e a produção de narrativas midiáticas sobre a ocupação é o que iremos analisar a seguir.

\section{A cena reconstruída em conexão com a trama jornalística: apontamentos insurgentes}

A ocupação do Fernão Dias foi consolidada nos dias que se seguiram e os estudantes se manteriam firmes em suas reivindicações, mesmo com o cerco policial em torno da escola e com as ameaças das autoridades. No dia seguinte à tomada da escola pelos estudantes, o jornal Folha de S. Paulo 


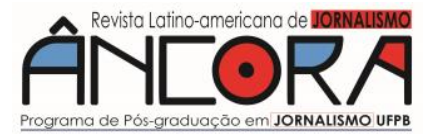

Francine ALTHEMAN - Ângela MARQUES

estampa na capa uma matéria (Figura 1 e 2) sobre o movimento secundarista, dando ênfase para a ocupação da E. E. Fernão Dias.

Figura 1 - Capa do jornal Folha de S. Paulo, com destaque para a manchete sobre a ocupação

\section{FOLHA DE S.PAULO}
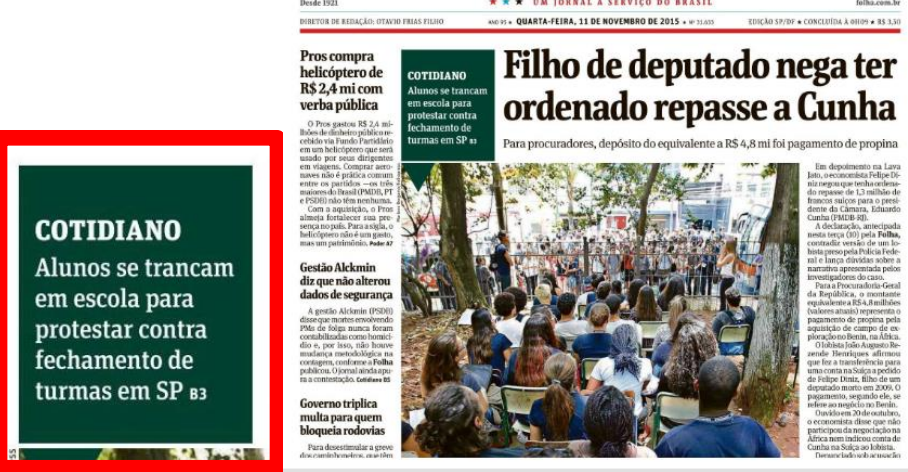

Fonte: Folha de S. Paulo, 2015

Figura 2 - Parte da matéria publicada no jornal Folha de S. Paulo sobre a ocupação

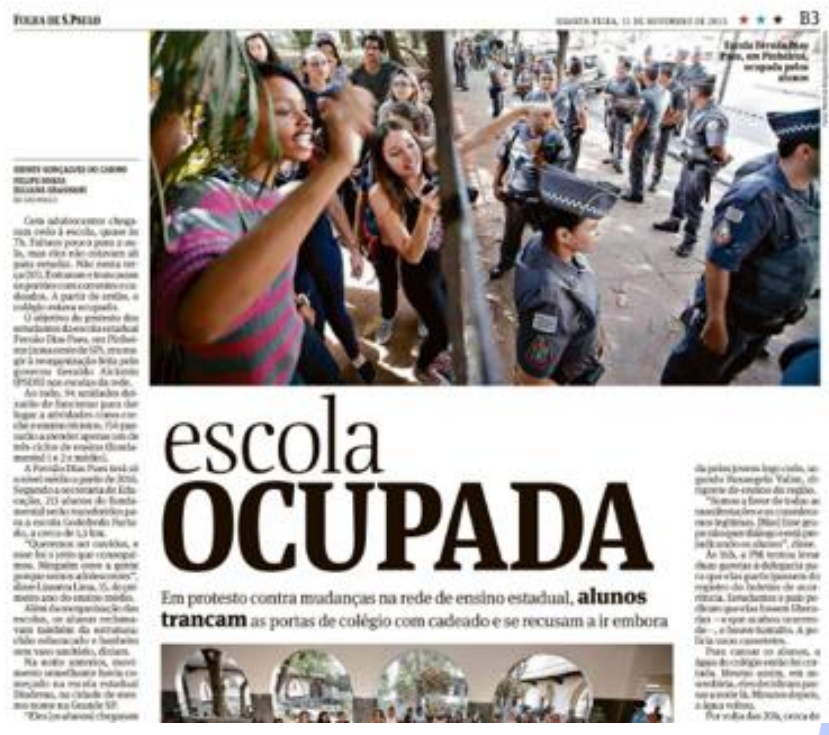

Fonte: Folha de S. Paulo (CARMO, SOUZA e GRAGNANI, 2015)

Importante observar que a reportagem trata o movimento como uma ocupação, conferindo destaque às tentativas de desarticular o movimento, como a presença da polícia (que aparece na foto principal) e o corte de água 
e energia que a diretoria solicitou, que foram restauradas horas depois. Além disso, a reportagem mostra o cuidado dos estudantes da organização em promover assembleias e manter a escola funcionando, como vemos nas imagens da matéria abaixo.

Figura 3 - Parte da matéria publicada no jornal Folha de S. Paulo sobre a ocupação
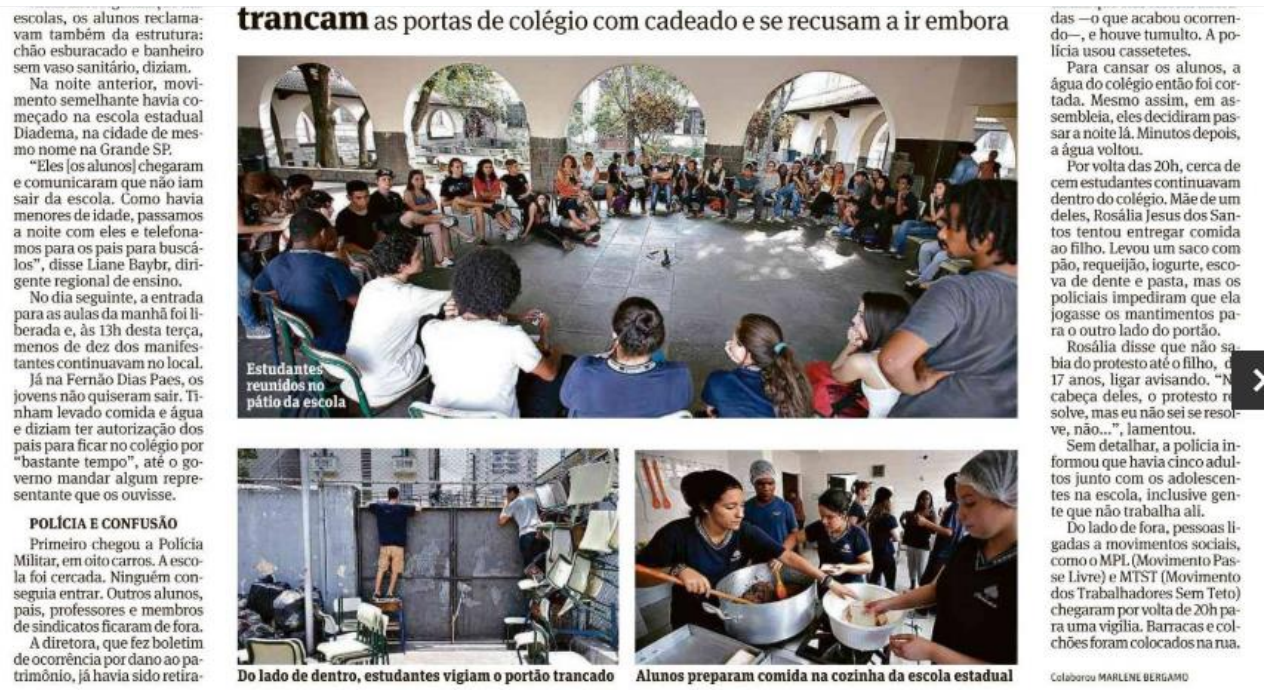

Fonte: Folha de S. Paulo (CARMO, SOUZA e GRAGNANI, 2015)

No entanto, o jornal muda o tom de suas reportagens sobre 0 movimento secundarista dois dias depois. Em matéria publicada no dia 13 de novembro, a Folha de S. Paulo passa a adotar o termo "invasão" para retratar as ocupações das escolas. É importante fazer essa consideração, porque ao usar o termo "invasão" a reportagem atribui um enquadramento diferente ao movimento, associando-o a algo ilegal e depreciativo, o que pode causar repulsa no público que acompanha os acontecimentos e argumentos negativos na formação da opinião pública. Todas as matérias publicadas pelo jornal a partir de então seguem esse mesmo tom de culpabilizar os estudantes. 


\section{ÂN[ORA}

Francine ALTHEMAN - Ângela MARQUES

Figura 4 - Parte da matéria publicada no jornal Folha de S. Paulo, usando o termo "invasão"
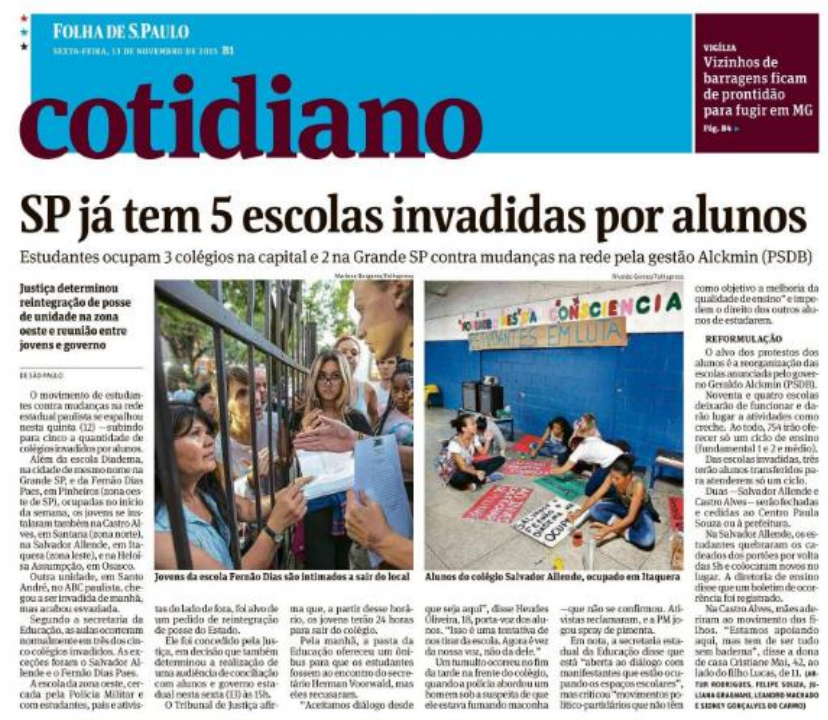

Fonte: Folha de S. Paulo (RODRIGUES, MACHADO, CARMO, SOUZA, GRAGNANI, 2015)

Essa questão que envolve o uso da palavra "ocupação" ao invés de "invasão" é muito importante para os secundaristas, tanto que eles enfatizam frequentemente a não neutralidade do uso da terminologia na composição das narrativas que publicizam suas ações. Para eles, os veículos de comunicação que usam o termo "invasão" para se referirem ao movimento contribuem para sua despolitização e corroboram uma forma de visibilidade favorável à governamentalidade biopolítica, através do uso de enquadramentos que acionam pânico moral e incitam um julgamento depreciativo. Os alunos passam a se negar a conceder entrevistas para jornalistas que trabalham nesses veículos de mídia. Um sentimento de tristeza misturada com revolta transparecia nos relatos de redes sociais quando narrativas acerca do movimento na mídia não os consideravam como interlocutores e, mais ainda, como protagonistas do movimento.

Eu acho que também tem essa coisa que é muito difícil pautar a discussão com a sociedade. Porque a todo momento que você tem que construir uma luta, e aí você, ainda em cima da construção dessa luta, precisa se preocupar com a opinião 
pública e a gente não tem controle da mídia. $A$ gente sabe que tem alguns setores da sociedade que tem controle da mídia (Andreza Delgado, estudante que apoiou o movimento, entrevista concedida em 2015) ${ }^{7}$.

Ainda nas primeiras semanas de ocupação, ao dar entrevista para uma repórter da Folha S. Paulo que gravava um vídeo sobre as ocupações para uma reportagem da TV Folha, a estudante Giovana Pazini deixa clara a preocupação dos secundaristas com a cobertura equivocada da mídia.

Nós estamos ocupando a escola desde o começo da semana passada, ocupando, hein, não invadindo. E aqui é um pessoal super organizado, é um pessoal super de boa, tranquilo. Não tem nada do que o pessoal pensa, sabe? Não tem baderna, pelo contrário. A gente está deixando a escola melhor do que ela é quando a gente estuda nela. Tem até papel higiênico no banheiro (Giovana Pazini, E. E. Fernão Dias, e entrevista à TV Folha, 2015 - grifo nosso).

A reportagem, veiculada dias depois na $T V$ Folha, do jornal Folha de $S$. Paulo, mostrava o dia a dia de quatro escolas ocupadas: Diadema, Fernão Dias, Salvador Allende e Brigadeiro Gavião. Como a matéria foi produzida com depoimentos dos secundaristas e imagens das ocupações dessas quatro escolas, deixava evidente a organização dos estudantes, com imagens dos mesmos limpando a escola, cozinhando, cuidando dos equipamentos, fazendo debates. Assim, a reportagem provava que os estudantes não estavam depredando, destruindo ou fazendo baderna nas escolas, como o governo do Estado repercutia na tentativa de desmoralizar o movimento. Dias depois de veiculada, a reportagem foi tirada do ar sem explicações.

No entanto, uma matéria de duas páginas, publicada no dia 15 de novembro de 2015 no jornal (Figura 5), traz praticamente o mesmo conteúdo do vídeo, o dia a dia da ocupação no Fernão Dias, visitada pela reportagem, a qual também mostrava a organização da ocupação. Como a matéria foi

\footnotetext{
7 Depoimento transcrito do documentário: LUTE como uma menina! Direção e produção: Flávio Colombini e Beatriz Alonso. São Paulo: 2016. Documentário (77 min). Disponível em: <https://www.youtube.com/watch?v=80CUMGHm2oA\&t=1157s\&list=PLx6HesqJ7yTiTG-

MQ8YBFce84NV9OQjwm\&index=4>.
}

João Pessoa - Brasil | ANO 8 VOL.8 N.1 | JAN./JUN. 2021 | p. 121 a 152

Revista Latino-americana de Jornalismo | ISSN 2359-375X

Programa de Pós-Graduação em Jornalismo - UFPB

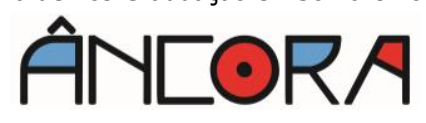




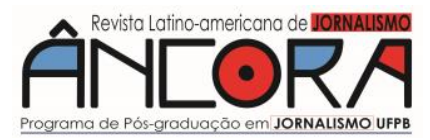

Francine ALTHEMAN - Ângela MARQUES

veiculada na versão impressa do jornal, ela não pode ser retirada de circulação, como o vídeo.

Figura 5 - Parte da matéria publicada no jornal Folha de S. Paulo sobre o dia a dia da ocupação

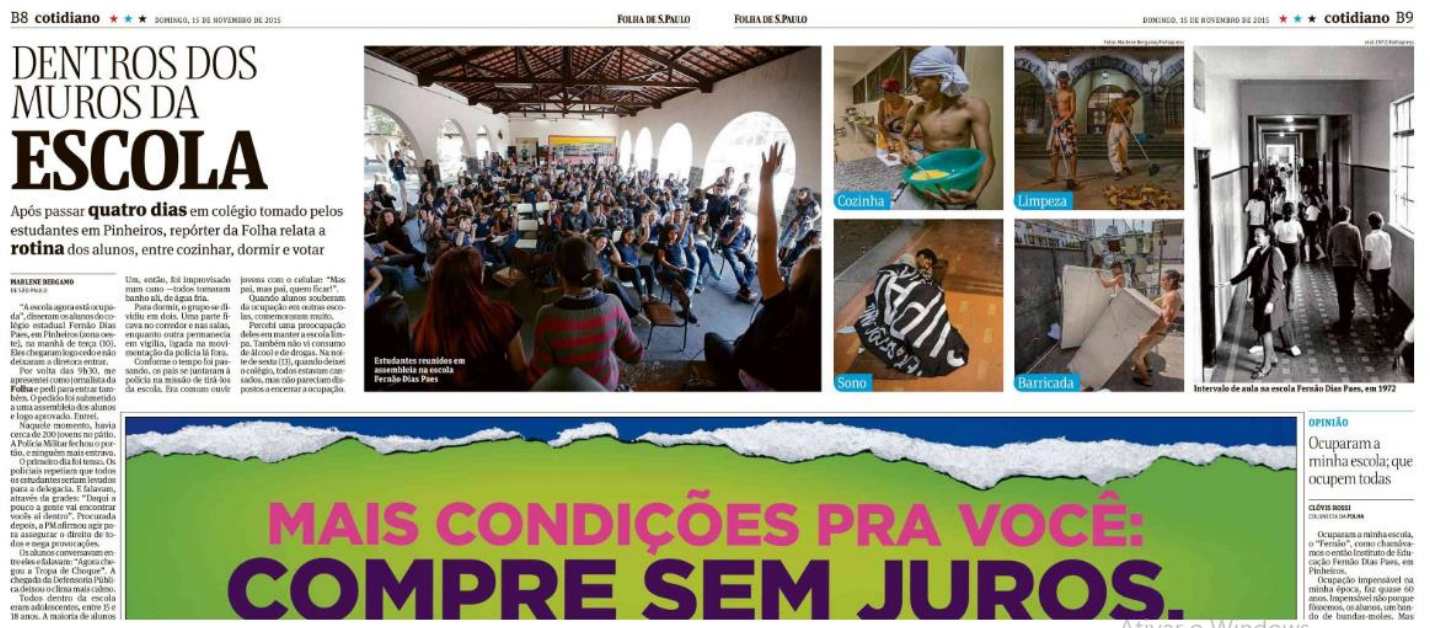

Fonte: Folha de S. Paulo (BERGAMO, 2015)

Na mesma edição, no entanto, em outra página, em matéria produzida para falar da atuação dos pais na ocupação do Fernão Dias (Figura 6), o jornal volta a usar o termo "invasão", com foco no cerco policial e na fala do governo sobre os benefícios da reorganização escolar.

Figura 6 - Parte da matéria publicada no jornal Folha de S. Paulo sobre a ocupação na E. E. Fernão Dias

\section{Pais se revezam em vigília diante de escola}

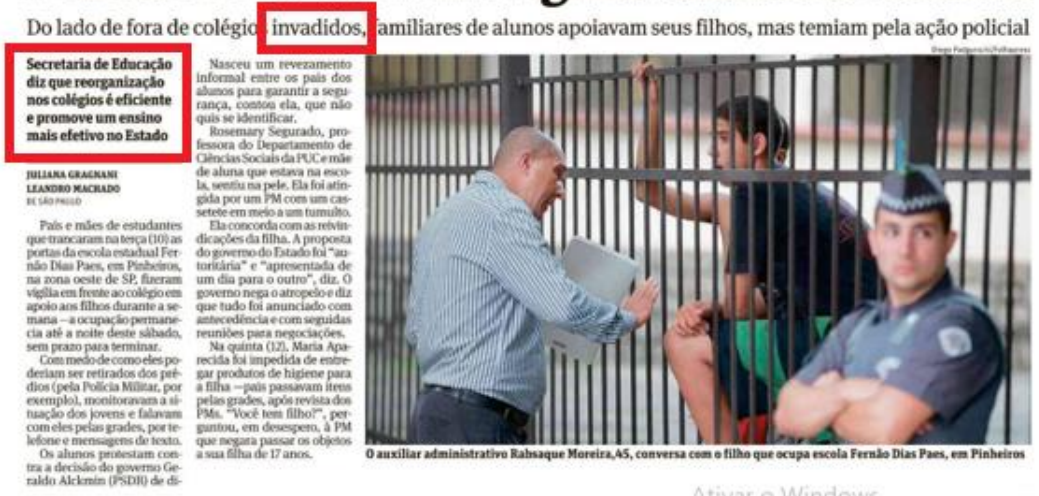

João Pessoa - Brasil | ANO 8 VOL.8 N.1 | JAN./JUN. 2021 | p. 121 a 152 
Fonte: Folha de S. Paulo (GRAGNANI, MACHADO, 2015)

É importante olhar para os modos de "aparência" performática dos sujeitos na imagem e questioná-los em busca das fissuras que nos indicam que a moldura do enquadramento não consegue determinar de forma precisa o que vemos, pensamos, reconhecemos e apreendemos. 0 enquadramento, como destaca Butler (2018), não é capaz de conter completamente o que transmite e, por isso, se rompe toda vez que tenta dar uma organização definitiva a seu conteúdo. Pior: o enquadramento que torna os vulneráveis visíveis (e suas demandas legíveis) nos discursos midiáticos contribui negativamente para intensificar sua precariedade e apagamento.

As experimentações políticas das ocupações têm em seus processos comunicativos uma de suas bases principais, bem como a forma de "aparecer" para o público, seja por meio das narrativas tecidas pelos veículos de mídia tradicionais, seja por meio de novas formas de fazer comunicação e circular relatos. Enfatizamos que "aparecer" não se reduz a adquirir visibilidade, mas envolve alterar o modo como sujeitos são percebidos e reconhecidos diante dos outros, o que demanda um deslocamento do olhar, uma outra forma de imaginar a alteridade e de considerar as formas de vida daqueles que se apresentam diante de nós mediadas pelos relatos e enquadramentos midiáticos (MARQUES; ALTHEMAN, 2020).

Em suas obras mais recentes, Rancière $(2018,2019)$ e DidiHuberman (2016b, 2019) exploram, cada um a seu modo, as operações enunciativas que produzem uma tensão entre regimes de visiblidade e controle das vidas, salientando que o apagamento e o desaparecimento de sujeitos e povos minoritários relaciona-se à manutenção de regimes de visibilidade e racionalidades afetivas que produzem obstáculos para o "aparecer" insurgente de demandas dissensuais e subjetividades "desviantes". Ambos se preocupam com as possibilidades de tornar legíveis 


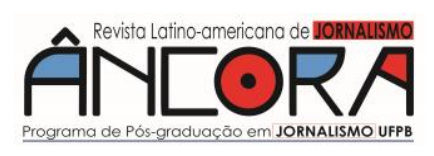

Francine ALTHEMAN - Ângela MARQUES

e inteligíveis formas de vida na imagem, na fiç̧ão e nas narrativas acerca de acontecimentos históricos. Eles ressaltam que a capacidade de "aparecer" de sujeitos minoritários manifesta-se em uma espécie de montagem que, ao reunir várias imagens, documentos e relatos, pode revelar a fratura causada por representações preconceituosas que aprofundam desigualdades.

As perspectivas de Rancière e de Didi-Huberman nos auxiliam a ver como, nessas narrativas jornalísticas e no âmbito de sua circulação, as cenas configuradas pelos estudantes secundaristas são materializadas a partir de uma tensão constante entre duas formas de tornar legíveis e inteligíveis formas de vida e de resistências nas textualidades que organizam os acontecimentos: uma racionalidade policial que articula os fatos dentro de uma reprodução consensual daquilo que é "tido como dado" e uma racionalidade política, capaz de reconfigurar e redispor esses elementos, desafiando os enquadramentos usuais que conferem sentido aos eventos, assim como suas lógicas assimétricas de poder.

Essa operação do enquadramento silencia os jovens conferindo-lhes uma espécie de visibilidade invisibilizadora. Honneth (2003) não associa a invisibilidade a uma não presença física, mas sim a uma não existência social e comunicacional. O "aparecer" na cena de visibilidade só se concretiza quando um indivíduo sabe que foi considerado, escutado por seus parceiros na interação através de reações claras, as quais revelam que a outra pessoa mostra que ela o percebe. Sob esse aspecto, a vulnerabilidade moral envolve constrangimentos às condições de reconhecimento de um indivíduo como participante de relações recíprocas de diálogo. Nessa narrativa do acontecimento realizada pela Folha de $S$. Paulo existe um apagamento dos estudantes, mesmo que eles pareçam visíveis nas reportagens, é uma visibilidade invisibilizadora, pois não considera o que os estudantes expressam em suas demandas, o uso da palavra "ocupação", por exemplo, ao invés de 
"invasão", ou na tentativa de conter as imagens da ocupação, expressas pelo vídeo produzido pela $T V$ Folha e retirado do ar.

\section{Outras narrativas jornalísticas possíveis}

O percurso que elaboramos para reconstruir a cena da ocupação da Escola Estadual Fernão Dias passa necessariamente por essa análise da cobertura midiática, especialmente porque, como vimos, o Fernão se tornou a escola símbolo das ocupações, diversas vezes retratada nos veículos de comunicação. Quando observamos a cobertura de outros veículos, como UOL, do Grupo Folha, e G1, do Grupo Globo, verificamos que foi mantida a palavra "ocupação" na construção das matérias, adotando uma postura mais empática ao movimento, pelo menos no que se referia às ocupações. Há que se destacar que o movimento secundarista já ganhava a simpatia de vários setores da sociedade, como a classe artística, que frequentava as ocupações. Assim, o enquadramento midiático utilizado por grande parte dos veículos de comunicação seguiu uma tendência de camuflar a agressividade dirigida aos estudantes.

Apesar de o G1 (Figura 8) usar termos mais próximos das falas dos secundaristas para cobrir o movimento, podemos observar também que a matéria dá ênfase ao cerco policial, assim como a matéria do UOL (Figura 7), tendendo, em alguns momentos para uma cobertura sensacionalista, que também retrata o estudante de uma forma negativa, ao dizer, já na linha fina da matéria, que os estudantes impedem a entrada das pessoas e que se negam ao diálogo, enquanto que os estudantes, na verdade, buscaram o diálogo por mais de um mês e foram ignorados. Os estudantes não ficam exatamente esquecidos nas matérias mencionadas, mas eles têm pouco espaço de expressão. Como protagonistas do movimento, seria esperado que eles fossem destacados na reportagem. Além disso, a reportagem do G1 


\section{ÂNEORA}

Francine ALTHEMAN - Ângela MARQUES

(Figura 8) dá voz aos pais dos alunos que estão na porta da escola, com ênfase na tensão e preocupação destes com seus filhos.

A partir dessas observações é possível compreender que as narrativas jornalísticas apresentadas pelas coberturas mencionadas estabelecem um modo de compreensão do mundo, compõem uma rede de relações entre textos, os quais ordenam e expressam um mundo fabricado (LEAL, 2013). A prática narrativa configura o jornalismo como modo de conhecimento: ela produz intrigas, agencia fatos e elabora representações e enquadramentos para acontecimentos situados, conferindo-lhes sentido de maneira dinâmica. Tal prática age sobre o real, "pois articula os fatos de modo peculiar e próprio, criando e configurando legibilidades e imaginários específicos" (LEAL, 2013, p.35).

Para Juliana Gutmann (2006, p. 46), a narrativa jornalística não se reduz a representar acontecimentos, mas revela, na articulação de materialidades e textualidades, uma enunciação situada historicamente: "uma rede de significados endereçados por um sujeito ou sujeitos constituídos socialmente para outros sujeitos, todos imersos nas circunstâncias históricas e nas contingências sociais". Essa rede de significados, nas quais circulam quadros de sentido e pistas interpretativas, funciona, em grande medida, para ordenar narrativamente e ideologicamente (a partir de valores e padrões morais em voga) os episódios interacionais e os comportamentos que nos permitem construir imaginários compartilhados, como se pode observar nas coberturas da ocupação da escola Fernão Dias.

O jornalismo não produz ficções, "mas fabulações, criações acerca do vivido em processos de apreensão, textualização e circulação dos acontecimentos sociais sob a forma de notícias" (LEAL, 2013, p.33). É no gesto fabulador que permeia a criação e recriação de representações, que existe uma permanente tensão entre um mundo que se encontra já constituído e os esforços dos sujeitos para modificarem estruturas representativas e, nesse 
processo, constituírem seu auto entendimento (SOMERS; GIBSON, 1994; MARQUES, 2007). Como salienta Antunes (2008), narrativas não são apenas sequências de fatos encadeados de maneira causal e obedecendo a uma ordenação cronológica: elas podem configurar, a partir de suas materialidades (texto, imagens, legendas, fontes tipográficas, paginação, etc.), arranjos verbovisuais capazes de alterar a percepção e legibilidade acerca de um dado acontecimento. Sob esse aspecto, entendemos as narrativas jornalísticas como textualidades que vão além de uma representação dos acontecimentos, pois permitem uma disposição específica de múltiplos elementos, estabelecendo entre eles um conjunto de relações e interfaces. Segundo Leal (2013), tais relações permitem a coexistência de temporalidades, espacialidades e corporeidades, alterando as possibilidades de apreensão, de interpretação e de apropriação dos acontecimentos.

Sob esse aspecto, as textualidades e narrativas jornalísticas nos interessam não a partir de uma análise de conteúdo, mas a partir da possibilidade de elas serem apropriadas e entrelaçadas em uma rede de eventos singulares, como um dos elementos que ajudam a construir uma cena de insurgência. Elas configuram uma certa topografia, uma disposição e redisposição de elementos argumentativos e sensíveis que interferem na distribuição das possibilidades de mudanças e de coexistências entre espaços, tempos e subjetividades. 


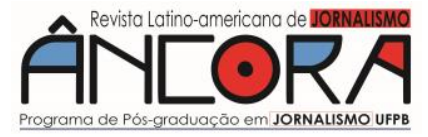

Francine ALTHEMAN - Ângela MARQUES

Figura 7 - Parte da matéria publicada no portal UOL sobre a ocupação da E. E. Fernão Dias
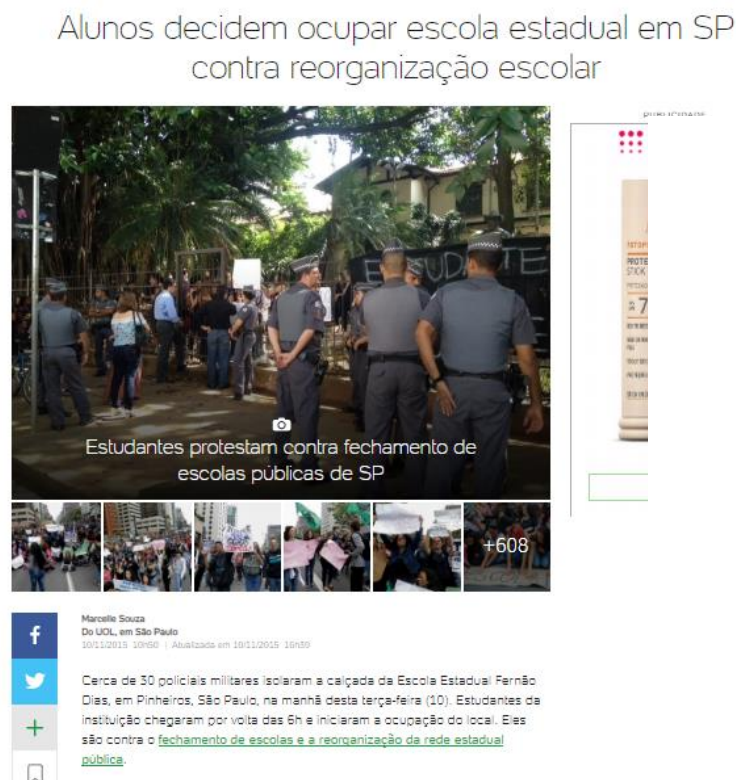

Fonte: UOL (SOUZA, 2015)

Figura 8 - Parte da matéria publicada no G1 sobre a ocupação da E. E. Fernão Dias

Estudantes ocupam escola em São Paulo contra fechamento de unidades Jovens impediram entrada na EE Fernão Dias Paes, que não será fechada. PM acompanha ato; secretaria registrou boletim como depredação.

Carollna Dantag
Da G1 Sía Paula \begin{tabular}{|l|l|l|l|}
\hline If FACEOOK & I & \& & (1) \\
\hline
\end{tabular}

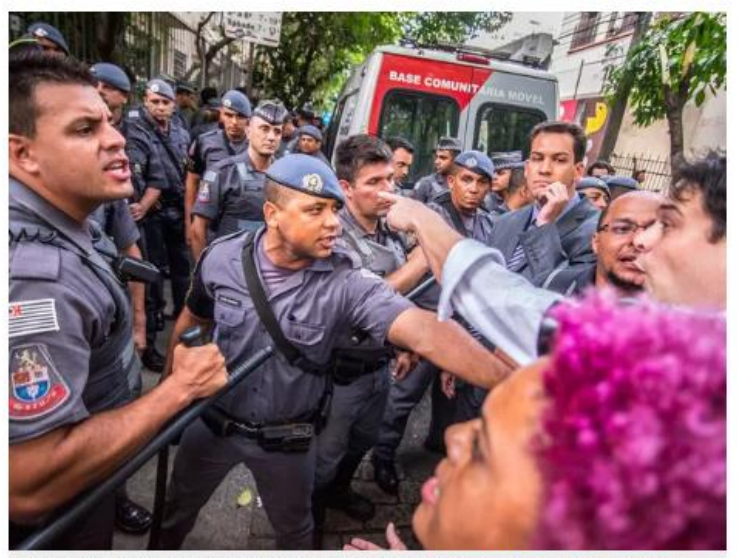

Policiais miltares discutem com manifestantes em frente à Escola Estadual Fernão Dias Paes, em Pinheiros
(Foto: Cris Faga/ Fox Press Photo: Estadalo Conteido)

Estudantes ocuparam a Escola Estadual Fernão Dias Paes, em Pinheiros, na Zona Oeste deSão Paulo na manhã desta terca-feira (10) O protesto é contra o fechamento de escolas para a reorganização da rede de ensino estadual. Um grupo também entrou em outra escola Fonte: G1 (DANTAS, 2015)

João Pessoa - Brasil | ANO 8 VOL.8 N.1 | JAN./JUN. 2021 | p. 121 a 152 Universidade Federal da Paraíba 
Nessa imagem publicada pelo $G 1$, há uma linha diagonal imaginária que separa policiais e estudantes e coloca os policiais em uma posição de imposição de força. Mas ao enfrentarem os policiais, os estudantes rompem com a previsibilidade da história e refutam a regra (DIDI-HUBERMAN, 2016a). Eis a sublevação, o levante que fratura e interdita a confirmação de uma história que todos esperavam que se realizaria como esperado: a submissão dos estudantes diante do poder disciplinar. É importante destacar a forma como os levantes surgem como gestos, formas corporais, antes mesmo de serem atos ou ações. São potências nativas, que começam com um clamor, como um grito e assumem depois a forma de uma onda, com seus avanços e retrações (DIDI-HUBERMAN, 2019).

Outros veículos de comunicação também cobriram as ocupações em São Paulo, com diferentes abordagens e linhas editoriais, alguns mais próximos do movimento, como o veículo independente Jornalistas Livres (Figura 10), que deixava claro seu apoio às ocupações, incorporando assim a figura do jornalista-militante, e outros com uma preocupação em trazer uma visão mais analítica do movimento, como o El País Brasil(Figura 9), que fez uma cobertura baseada nas falas dos secundaristas, dando voz a eles muitas vezes, com fontes especializadas, como professores e especialistas em assuntos de resistência, e analisando criticamente o papel do Estado nesse contexto da insurgência secundarista. 


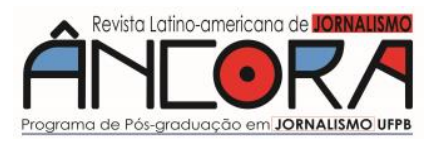

Francine ALTHEMAN - Ângela MARQUES

Figura 9 - Manchete de matéria publicada no El País Brasil sobre as ocupações das escolas

$$
\equiv \text { ELPAIIS }
$$

MANFESTAĢōes ESTUDANTES Săo PaULo :

Por que a reforma que afeta 300.000 alunos em SP virou caso de polícia?

Para especialistas, falta de planejamento do Governo estadual agravou a crise

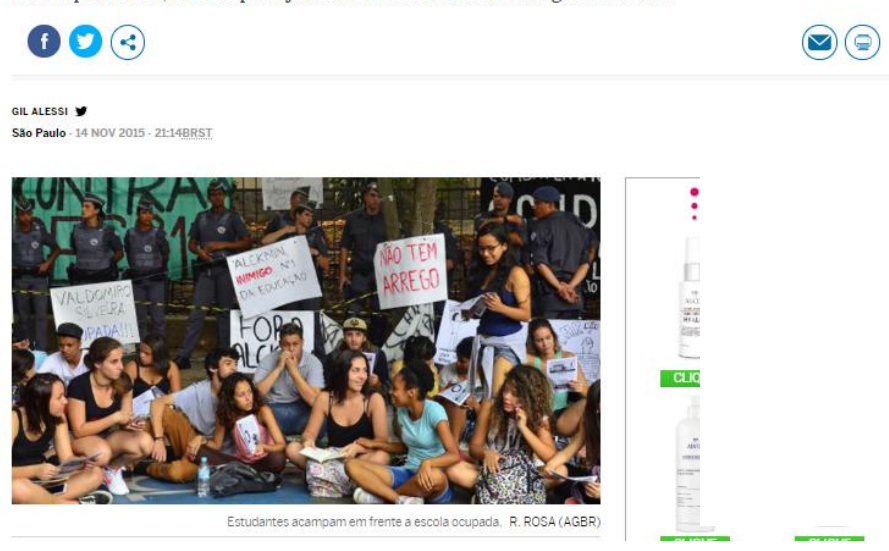

Fonte: El País Brasil (GIL, 2015)

Figura 10 - Parte de matéria publicada no Jornalistas Livres sobre a ocupação da E. E. Fernão Dias

M jornalistas livres

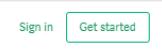

\footnotetext{
Escolas ocupadas: a Fernão resiste

Audiência de conciliação definirá rumos do movimento de ocupação

das escolas estaduais de São Paulo. Se não houver acordo, estudantes

terão 24 horas para desocupar escola antes da reintegração de posse.

(4) Iornalistas Lives Follow

ข $\boldsymbol{1}$ ロ

Por Maria Carolina Trevisan*, especial para Jornalistas Livres

Com imagens de Paulo Ermantino, Sato do Brasil, Renata Simões e Taba Benedicto

Uma barreira de policiais militares separa a rua dos muros da Escola

Estadual Fernão Dias Paes, em Pinheiros, zona oeste de São Paulo. Ocupada

por estudantes, a maioria adolescentes, desde a manhã de terça-feira

(10/11), a escola está isolada por fileiras de carros da PM, motos da Ronda

Ostensiva de Apoio de Motocicletas (Rocam), homens da Força Tática e

soldados da Polícia Militar armados. Do lado de dentro, alunos se revezam

em vigilia, cozinham e limpam o "Fernão". Nada foi depredado.
}
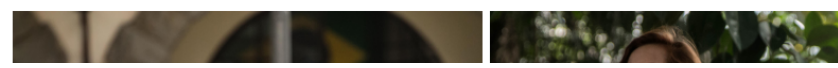

Fonte: Jornalistas Livres (TREVISAN, 2015)

Interessante observar que, diferentemente dos outros veículos de comunicação que enfatizam o cerco policial e a disputa com a polícia, as imagens que compõem a matéria do portal Jornalistas Livres dão protagonismo 
somente aos estudantes, com seus rostos, corpos e gritos aparecendo em primeiro plano, como que mostrando ao público que este movimento tem cara e tem reivindicações justas (Figura 11).

Figura 30 - Parte de matéria publicada no Jornalistas Livres, com ênfase nas imagens da matéria
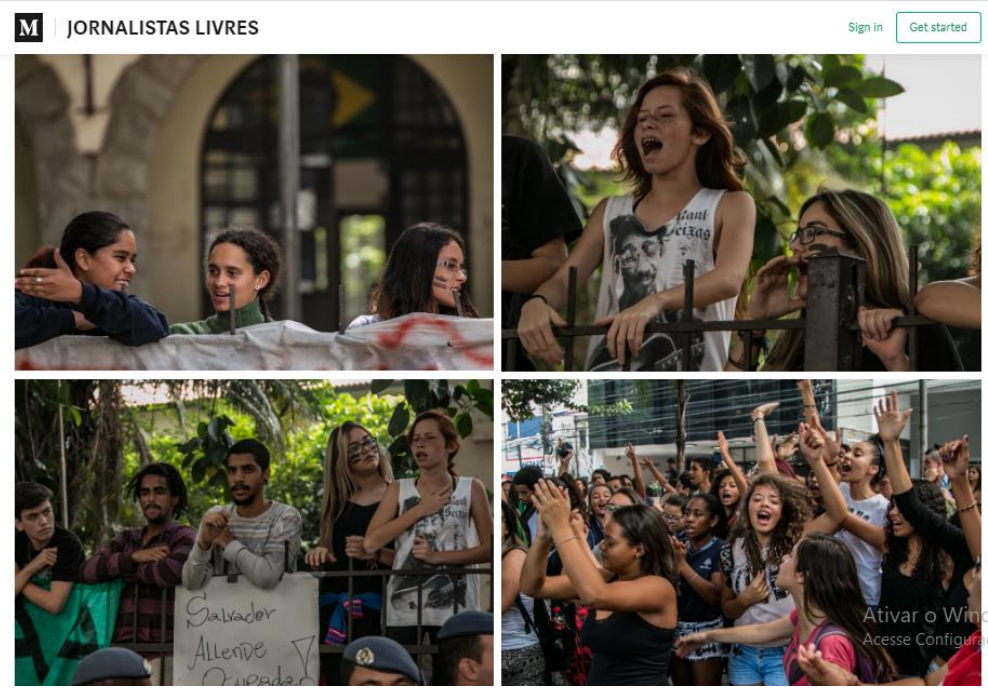

Fonte: Jornalistas Livres (TREVISAN, 2015)

A escolha das imagens que compõem as matérias veiculadas pelo $E /$ País Brasil e pelo Jornalistas Livres foge do padrão normalmente visto nas coberturas dos veículos tradicionais e busca dar protagonismo aos estudantes. É o que Didi-Huberman (2012, 2016b) chama de imagem-sintoma, ou seja, uma operação que busca nos tornar sensíveis a algo na história de um povo, a ponto de desejarmos conhecer e acompanhar essa trajetória mais de perto.

Nesse sentido, apesar de a imagem que ilustra a matéria do El País Brasil (Figura 9) trazer os policiais fazendo um cerco aos estudantes, estes estão em primeiro plano, sorrindo, produzindo cartazes, mostrando sua potência como movimento, enquanto uma linha, representada por uma fita, separa os alunos dos policiais, que estão visivelmente incomodados, como se eles não pertencessem àquela fotografia. Já nas quatro imagens que ilustram a matéria do Jornalistas Livres (Figura 11), o protagonismo é todo dos 


\section{AीNएक्रू}

Francine ALTHEMAN - Ângela MARQUES

estudantes. É possível perceber que os policiais estavam ali, parte das suas cabeças aparece em uma das imagens, mas eles não ganham importância nessas fotografias. Os secundaristas, por sua vez, estão radiantes, com seus rostos pintados, altivos, os corpos em movimento, gritando e mostrando a potência daquele momento de ocupação. Como afirma Didi-Huberman (2016a, 2019), o levante é uma composição de forças, cujo resultado é uma exclamação de afetos e de cólera. "O levante começa como um clamor, um grito. [...] murmúrio, rumor: logo uma exclamação, um grande clamor" (DIDIHUBERMAN, 2016a, p. 344).

Nas cenas reconstruídas nesse tópico, um importante dispositivo de comunicação está presente: a imprensa considerada alternativa, independente, especialmente representada pelos repórteres do Jornalistas Livres, portal de notícias formado em 2013, durante as Jornadas de Junho, que tem como proposta fazer uma cobertura independente dos grandes veículos de mídia.

A mídia independente, como o Jornalistas Livres e o Mídia Ninja, surge no Brasil e no mundo na seara dos mais novos movimentos sociais. Eles se inserem em um contexto midiático em que a internet e as redes sociais digitais possuem um espaço cada vez maior, por isso eles definem o jornalismo produzido por eles como uma grande rede, na qual circula uma narrativa jornalística independente, calcada na ação. Eles também reforçam a ideia de um jornalismo colaborativo, em que os participantes são produtores e consumidores da informação (FERREIRA, 2016).

Além disso, eles promovem coberturas em tempo real, no calor do acontecimento, gravando em plano-sequência, sem edição, que acabam sendo aproveitadas, inclusive, por outros veículos. Eles passam, portanto, a ser considerados uma ferramenta política e midiática na cobertura de manifestações. 
No caso das ocupações dos secundaristas, a presença de repórteres do Jornalistas Livres na maior parte dos eventos promovidos pelos estudantes garantiu uma cobertura que se aproxima dessa juventude militante e, ao mesmo tempo, se configurou como um dispositivo que manteve, em certa medida, a segurança dos secundaristas. Em algumas cenas reconstruídas dos protestos nas ruas, alguns estudantes aparecem sendo levados por policiais ou em clara disputa com o policial, cuja agressividade extrema fica evidente. Nesses casos, o fato de o repórter acompanhar todos os passos dos estudantes e registrar diversas cenas de violência policial, colabora para dar visibilidade à forma truculenta com que esses estudantes são tratados e ajuda a protegêlos de violência mais extrema. Pode-se observar, portanto, que a presença da imprensa inibe o uso da força e da violência.

As narrativas jornalísticas exploradas nesta seção revelam como é possível alterar esquemas de inteligibilidade do mundo, criando uma pequena "máquina de desmontagem do olhar" que interrompe o estava programando para poder ser visto. Depois da expectativa não realizada, a experiência se expande, "alterando o estatuto do visível, da maneira como olhamos as coisas e de como nos movemos entre elas" (RANCIÈRE, 2019, p.51).

\section{Considerações finais}

$\mathrm{Na}$ pesquisa desenvolvida sobre o movimento secundarista, interessava-nos compreendê-lo como uma potencialidade de emancipação política, compondo com as falas dos sujeitos envolvidos; ainda nos interessava refletir sobre o sistema de relações que se constituem a partir das ocupações, e que levam a um rearranjo tanto dos sujeitos envolvidos, quanto dos sistemas midiáticos. Assim, consideramos que as narratividades e textualidades jornalísticas possibilitam o que Didi-Huberman (2016a) chama de "tornar 


\section{ANIEORA}

Francine ALTHEMAN - Ângela MARQUES

sensível o olhar", ou seja, elas configuram um modo de experimentar o mundo, de posicionar-se diante dele e de se inserir em seus contextos.

O aparecer dos secundaristas nas narrativas jornalísticas e nas cenas que podem ser montadas a partir de suas interfaces e articulações produz uma operação delicada de questionar o enquadramento hierárquico e consensual, de interpelá-lo em busca das fissuras que indicam que a moldura não consegue determinar de forma precisa o que vemos, pensamos, reconhecemos e apreendemos. No lugar de discursos de causalidade e de apagamento das sutilezas e texturas das experiências, é importante apostar na escolha de outro enquadramento para "ler" os enunciados, para abrir intervalos narrativos que permitam duas ações simultâneas: montar uma cena de dissenso e permitir aos espectadores uma outra forma de legibilidade do tempo e do comum.

Essa dimensão da operação de montagem que envolve dialetizar o visível e tornar sensível nos interessa mais de perto, porque permite a indecidibilidade do espectador, que vacila (diante dos desencaixes entre o que vêem e suas expectativas) antes de emitir um julgamento moral definitivo e taxativo diante de uma narrativa. Sob esse aspecto, tornar sensível é também desarmar o olhar diante de explicações hegemônicas, solicitando outro imaginário e uma forma de consideração que se posiciona contra o apagamento das formas de vida no interior das textualidades jornalísticas.

Desse modo, após observar as coberturas realizadas pelos veículos de mídia analisados neste texto, consideramos que as narrativas jornalísticas são constelações de relações inseridas no tempo e espaço, constituídas por gestos fabuladores que oscilam, dialeticamente, entre a representação do mundo já dado e a redisposição de elementos que conferem legibilidade e inteligibilidade aos acontecimentos. Assim, tais narrativas produzem figurações, isto é, articulam "rastros de materialidades que nos oferecem condições de compreender a dinamicidade do sentido" (ROSA, 2019, p.30). 
Neste artigo, ao tratarmos de narrativas jornalísticas de insurgências, estamos entrelaçando as representações de cenas de ação secundarista no espaço físico às possibilidades de figuração e de circulação que regulam as condições de visibilidade e de afetação modeladas pelas avaliações e julgamentos morais definidos no âmbito dos dispositivos midiáticos.

Assim, foi possível perceber como as narrativas jornalísticas promovem diferentes modos de "aparecimento" de sujeitos insurgentes a partir de um momento de dissenso, de assimetria, de deslocamento que produz intervalos e disputas de sentido. A partir de reflexões feitas por Rancière $(2018,2019)$ e Didi-Huberman (2016b), avaliamos que ações insurgentes podem "descontinuar" as narrativas consensuais que tendem a explicar o mundo por meio de discursos e imaginários hierárquicos consolidados. Sob esse aspecto, Rancière (2019) caracteriza o aparecer (apparaître) como um gesto estético e político que promove uma outra forma de estruturação do "pensável", envolvendo a alteração de um regime de percepção, de leitura e de escuta por meio do qual elementos diversos se justapõem e se atritam de modo a permitir um deslocamento de nossa posição em relação ao modo como apreendemos, percebemos e respondemos às demandas do outro e aos eventos do mundo.

Rancière enfatiza seu interesse em observar como textos, imagens e performances podem nos fazer pensar acerca de um reposicionamento dos corpos, de um deslocamento de avaliações muito apressadas e de julgamentos fundados em pré-conceitos: como encontrar "uma forma de interromper a máquina da explicação das coisas" (RANCIĖRE, 2018, p. 17)? "Qual tipo de operação vai mudar essa distribuição do visível e do pensável?" (RANCIĖRE, 2019, p.50). De maneira muito próxima, Didi-Huberman (2016b) considera como narrativas insurgentes podem "dialetizar o visível", ou seja, podem deslocar formas usuais de representação e produzir, nesse processo, novos enquadramentos e novas possibilidades interpretativas. Segundo ele, "dialetizar o visível" (2016, p.405) destaca a "potência de legibilidade dos 


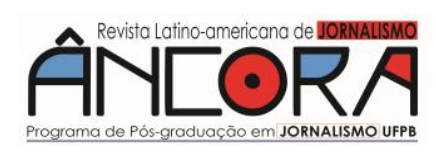

Francine ALTHEMAN - Ângela MARQUES

acontecimentos sensíveis", sobretudo através das imagens, que podem evidenciar operações de desumanização e silenciamento. Assim, dialetizar o visível implica também "tornar sensível" (rendre sensible), isto é, tornar acessível aquilo que nossos sentidos e inteligências nem sempre conseguem "ler" ou conferir sentido, permanecendo como indício, resto, algo que é geralmente desconsiderado pelo olhar.

\section{Referências}

ANTUNES, Elton. Acontecimento, temporalidade e a construção do sentido de atualidade no discurso jornalístico. Contemporânea (Salvador), v. 6, p. 121, 2008.

BUTLER, Judith. Corpos em aliança e a política das ruas: notas para uma teoria performativa de assembleia. Rio de Janeiro: Civilização Brasileira, 2018.

DIDI-HUBERMAN, Georges. Quando as imagens tocam o real. Pós: Belo Horizonte, vol. 2, no 4, p. 204-219, nov. 2012.

DIDI-HUBERMAN, Georges. Soulèvements. Paris: Jeu de Paume, Gallimard, $2016 a$.

DIDI-HUBERMAN, Georges. Peuples en larmes, peuples en armes. Paris: Éditions de Minuit, 2016b.

DIDI-HUBERMAN, Georges. Ondas, torrentes e barricadas. Serrote, no 33, p. 115-143, 2019.

FERREIRA, Thiago. Mídia Ninja e juventude: corpos e afetos nas disputas políticas e nas narrativas audiovisuais. In: JESUS, Eduardo et al. (orgs.).

Reinvenção comunicacional da política: modos de habitar e desabitar o século XXI. Salvador: EDUFBA; Brasília: Compós, 2016, p. 129-145.

GUTMANN, Juliana Freire. Quadros narrativos pautados pela mídia: framing como segundo nível do agenda-setting?Contemporanea, v. 4, p. 25-50, 2006.

HONNETH, Axel. Luta por reconhecimento. A gramática moral dos conflitos sociais. São Paulo: Editora 34, 2003.

LEAL, Bruno. Jornalismo à luz das narrativas: deslocamentos. In: Bruno Souza Leal; Carlos Alberto de Carvalho. (Org.). Narrativas e poéticas midiáticas: estudos e perspectivas. 1ed.São Paulo: Intermeios, 2013, v. 1, p. 25-48.

MARQUES, Ângela Cristina Salgueiro; ALTHEMAN, Francine. Cenas de insurgência e figurações secundaristas: potencialidades estéticas e políticas de seus arranjos disposicionais. Alceu, Vol. 20, no 40, 2020, p. 27-51. MARQUES, A. C. S. Ficção, Cotidiano e Narrativa: entre o visto e o vivido. Revista de Estudos da Comunicação, v. 8, p. 29-39, 2007. 
MENDONÇA, R.F.; SIMÕES, P.G. Enquadramento: diferentes operacionalizações analíticas de um conceito. Rev. Bras. Ciências

Sociais, v. 27 n. 79, 2012, p.187-235.

RANCIĖRE, Jacques. The method of equality: an answer to some questions. In: ROCKHILL, Gabriel; WATTS, Philip (eds.). Jacques Rancière: History, Politics, Aesthetics. Durham and London: Duke University Press, 2009, p.273-288.

RANCIÈRE, Jacques. The method of equality. Interviews with Laurent Jeanpierre and Dork Zabunyan. Cambridge: Polity Press, 2016.

RANCIĖRE, Jacques. Le méthode de la scène. Entretien avec Adnen Jdey. Paris: Lignes, 2018.

RANCIĖRE, Jacques. Le travail des images. Conversations avec Andrea Soto Calderón. Dijon : Les Presses du Réel, 2019.

ROSA, Ana. Circulação: das múltiplas perspectivas de valor à valorização do visível. Intercom, v. 42, p. 21-33, 2019.

SOMERS, Margaret \& GIBSON, Gloria. "Reclaiming the epistemological other: narrative and the social constitution of identity". In: CALHOUN, Craig (ed.) Social Theory and the Politics of Identity. Cambridge: Cambridge University Press, 1994, pp.37-80.

\section{Referências das reportagens analisadas}

ALESSI, Gil. Por que a reforma que afeta 300.000 alunos em SP virou caso de polícia? El País Brasil (on-line), 14 de novembro de 2015. Disponível em:

<https://brasil.elpais.com/brasil/2015/11/13/politica/1447426542 534410 . html>. Acesso em 19/12/2019.

BERGAMO, Marlene. Dentro dos muros da escola. Folha de S. Paulo, Caderno Cotidiano, p. B8 e B9, São Paulo, 15 de novembro de 2015. CARMO, Sidney Gonçalves do; SOUZA, Felipe; GRAGNANI, Juliana. Escola Ocupada. Folha de S. Paulo, Caderno Cotidiano, p. B3, São Paulo, 11 de novembro de 2015.

DANTAS, Carolina. Estudantes ocupam escolas em São Paulo contra fechamento de unidades. G1 (on-line), 10 de novembro de 2015. Disponível em: <http://g1.globo.com/sao-paulo/noticia/2015/11/alunosocupam-escola-em-sao-paulo-contra-fechamento-de-unidades.html > . Acesso em 19/12/2019. GRAGNANI, Juliana; MACHADO, Leandro. Pais se revezam em vigília diante da escola. Folha de S. Paulo, Caderno Cotidiano, p. B7, São Paulo, 15 de novembro de 2015.

LIVROS abertos, escolas ocupadas. Produção: Douglas Lambert. Fotografia e reportagem: Lígia Roca, Maíra Cabral, Marcus Leoni, Renan Lopes e Ricardo Lerman. São Paulo: TV Folha, 2015. Grande-reportagem (10 min). O material não está mais disponível on-line. 


\section{ÂN[ORA}

Francine ALTHEMAN - Ângela MARQUES

LUTE como uma menina! Direção e produção: Flávio Colombini e Beatriz Alonso. São Paulo: 2016. Documentário (77 min). Disponível em:

$<$ https://www.youtube.com/watch?v=80CUMGHm2oA\&t=1157s\&list=PLx 6HesqJ7yTiTG-MQ8YBFce84NV90Qjwm\&index $=4>$. Acesso em:

31/03/2019.

RODRIGUES, Artur; MACHADO, Leandro; CARMO, Sidney Gonçalves do; SOUZA, Felipe; GRAGNANI, Juliana. SP já tem cinco escolas invadidas por alunos. Folha de S. Paulo, Caderno Cotidiano, p. B1, São Paulo, 13 de novembro de 2015.

SOUZA, Marcelle. Alunos decidem ocupar escola estadual em SP contra reorganização escolar. UOL (on-line), 10 de novembro de 2015. Disponível em: <https://educacao.uol.com.br/noticias/2015/11/10/alunos-decidemocupar-escola-estadual-em-sp-contra-reorganizacao-escolar.htm >. Acesso em 19/12/2019.

TREVISAN, Maria Carolina. Escolas ocupadas: a Fernão resiste. Jornalistas Livres (on-line), 13 de novembro de 2015. Disponível em: $<$ https://medium.com/jornalistas-livres/escolas-ocupadas-afern\%C3\%A3o-resiste-235f60e24985>. Acesso em 19/12/2019. 